\title{
MARGINALIA ON 4QINSTRUCTION
}

\section{FLORENTINO GARCÍA MARTÍNEZ}

K.U. Leuven-R.U. Groningen

1. "The 'vessel' (or 'wife') of thy bosom" after all?

In his contribution to the Hommage à Józef T. Milik, John Strugnell, with his customary wit and erudition, discussed two passages related to the topic of women and marriage. ${ }^{1}$ One of them was taken from the forthcoming edition of 4QInstruction, 4Q416 2 ii $21,{ }^{2}$ where he read: וום אל תקל כלי היקכה , translated as "Moreover do not treat with dishonour the 'vessel' (or 'wife') of thy bosom." ${ }^{3}$ Following a suggestion of the late P. Benoit, Strugnell brought this text to bear on the interpretation of 1 Thess 4:4, where бкعvos is used. Soon after, Torleif Elgvin proposed a different interpretation both of כל כל akEvos, seeing it not as 'wife' but as "a euphemism for the male organ," a metaphorical meaning that already has in 1 Sam 21:6, an interpretation also followed by Jay E. Smith. ${ }^{4}$

More recently, Menahem Kister turned his attention to this text again and proposed a different reading which resulted in a different interpretation. ${ }^{5}$ Kister's argument proceeds in the following way. (1) He reads line 21 as a continuation of the two previous lines, and therefore interprets it as dealing with the same topic. He gives a

\footnotetext{
${ }^{1}$ J. Strugnell, "More on Wives and Marriage in the Dead Sea Scrolls (4Q416 2 ii 21 [Cf. 1 Thess 4:4] and 4QMMT § B)," Hommage à Józef T. Milik (eds. F. García Martínez and E. Puech; Paris: Gabalda, 1996) 537-47 (= RevQ 17 [1996]).

2 J. Strugnell, D. Harrington, and T. Elgvin (eds), Qumran Cave 4. XXIV: Sapiential Texts, Part 2 (DJD 34; Oxford: Clarendon Press, 1999), 108-110.

${ }^{3}$ DJD 34, 90 and 93. See also Plate IV which reproduces PAM 43. 511.

${ }^{4}$ T. Elgvin, “To Master His Own Vessel': I Thess 4:4 in Light of New Qumran Evidence," NTS 43 (1997) 604-19, and J.E. Smith, "Another Look at 4Q416 2 ii 21, a Critical Parallel to First Thessalonians 4:4," CBQ 63 (2001) 499-504.

${ }^{5}$ M. Kister, "A Qumranic Parallel to 1 Thess 4:4? Reading and Interpretation of 4Q416 2 ii 21," DSD 10 (2003) 365-70. See now B.G. Wold, "Reconstruction and Reading 4Q416 2 ii 21: Comments on Menahem Kister's Proposal," DSD 12 (2005) 205-11.
}

(C) Koninklijke Brill NV, Leiden, 2006

Also available online - www.brill.nl

Dead Sea Discoveries 13, 1 
consecutive meaning, and considers the whole as "a direct continuation of the section (b)." (2) He assigns תקל the value of a nif'al (tikkal) instead of the hif'il (takel), proposed by the editors, and (3) reads תוקכה instead of an alternative reading proposed by the editors themselves. The main difference, of course, is (4) the reading of the key word בלי as בלו or), a reading which changes the meaning of the whole sentence and effectively wipes out all possible references to 1 Thess 4:4. In Kister's words: "Instead of כלי חיקכה ("the vessel of your bosom"), one should read בלי דוקכה (or "כלי ") (תוקכה "'not [according to] your prescribed portion."

Kister's interpretation makes perfect sense, and it may offer a better explanation of the line than the one proposed by Strugnell. But when one looks closely, his four arguments are less strong that they first appear.

(1) Let us examine the need to connect this line with the previous lines and to see it as a continuation of the same topic. The editors have included a very useful note on the use of וגם 4 QInstruction on their comment to line 15 :

\footnotetext{
The word atself is disproportionately frequent in 4Q415 ff. (nineteen times against only sixty-four times in all other 1-11Q texts) and also very frequent in Sirach (sixty times); there it usually marks the start of verses, if not also of sections ... In Biblical Hebrew ונם need not introduce new sections or sub-sections; in other cases it merely emphasizes the first word of a stich. Certainly neither one of these descriptions of its functions would always hold for the usage of Sirach nor, as far as can be seen, for the several fragmentary occurrences in $4 \mathrm{Q} 415 \mathrm{ff}^{7}$
}

A quick look at the texts listed in the concordance, even if some of them are useless, seems to prove the case of the editors. This makes Kister's assumption that the contents need to be related to the previous lines less likely.

(2) The reading of a non-vocalized verb form depends, of course, on the general understanding of the sentence in which the verb appears, and both the nif $^{\prime} a l$ and the hif $^{\prime} i l$ forms of pare abundantly used in Biblical Hebrew. In 4QInstruction the verb appears twice, in our text and in 4Q418a 24:2; but there, unfortunately, it appears without any context which could help explain the form. In the rest of the

\footnotetext{
${ }^{6}$ Kister, "A Qumranic Parallel," 367, contrasting his understanding with the one of the editors of DJD 34, 108: "the preceding stichs although complete do not seem closely related in sense to it."

7 DJD 34, 104-5.
} 
texts from Qumran, although the most frequent form is the picel, both nif'al (24Q267 5 iii 3) and hif'il (4Q252 I 14) forms are found. The only reason Kister gives for his interpretation of the form is that it appears as an antonym of תתכבד on the previous line. But this argument depends on the assumption that the contents of one line follows from the previous line. Besides, Isa 8:23 offers an antonymous use of

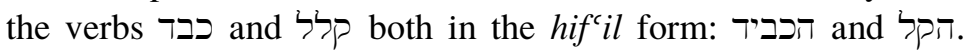

(3) Strugnell has signaled (in the "Notes on the Readings") that "[e]ither is materially possible, but considerations of sense and usage will decide which should be the reading." In the "Comments" he justifies his preference for the reading כלי חיקכה with what in my opinion is a strong argument: in 4Q416 2 iv 5 appears the expression

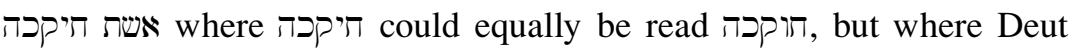
13:7 and 28:569 offers a parallel which assures the reading. Strugnell concludes that "it is unlikely that the same scribe would read הוקכה חיקכה in col. iv." standing an eventual כלי חוקכה would mean "lawful wife." Kister prefers to give תוק the meaning of "prescribed portion," a meaning which the word certainly has (for example on Prov 30:8), although it is not the most usual, particularly at Qumran, where the meaning of "statute, decree, law," and the like is overwhelming (not to say exclusive), as a look at the more than 150 entries of the word in Martin Abbeg's Concordance shows. ${ }^{11}$

(4) None of this, however, is definite. All is, we can say, circumstantial evidence that can be made to fit one interpretation or another. In the end everything hangs, of course, on the reading of a single letter. It is the reading of kaf or of beth in the twisted word (בלי/כלי) which commands the two different interpretations. Both in the article from the Hommage à Józef T. Milik, and in the DJD edition, Strugnell gives the reading of the kaf as certain, without any mark of an uncertain reading, as is the case with the yod of זיקכה. In DJD he signals in the "Notes on Readings": "The כלי can be read, though less clearly,

\footnotetext{
${ }^{8}$ DJD 34, 92.

9 This is the reference given in DJD; it should be 28:54, since 28:56 applies the expression to the man. 11QTemple 54:20 and MS A of Sirach 9:1 provide further parallels.

10 DJD 34, 108.

11 M.G. Abegg Jr. with J.E. Bowley and E.M. Cook, Dead Sea Scrolls Concordance (2 vols; Leiden: E.J. Brill, 2003) 1.254-56.
} 
also on 4Q417," 12 which implies that for him there is no doubt about the reading of 4Q416. Kister is equally assertive: "While in 4Q416 the traces of the first letter look more like beth than kaf, the traces of beth are clear in $4 \mathrm{Q} 417 .{ }^{\prime \prime 3}$

Direct examination of the originals is a strong argument indeedeven if palaeography is more of an art that a sciencesand since we have two scholars who assert they have read a beth against one who affirms having read a kaf, the matter could be closed (although the single scholar has had the longest period of direct contact with the originals since the fragments were acquired from the Bedouins). And, while in scholarship the rule of majority does not apply, the formal assertion of Kister and Qimron should normally close the case. Were it not for a careful re-examination of the different series of photographs of the two manuscripts in question, one might seriously question the notion that a recent direct examination could offer clarification.

In 4Q416, the oldest photograph, PAM 40.613 (taken on May 1953),${ }^{14}$ shows a completely preserved $k a f$; in 41.306 (October 1954) 41.783 (August 1955) and 41.903 (December 1955) the kaf is still rather complete, and is clearly recognizable, though it has been split in the middle. PAM 42.566 (May 1958) and PAM 42.702 (the first photograph where columns ii and iii have been put together, taken in August 1958) show how the manuscript had deteriorated in the meantime: only the top (which in this type of letter can correspond both to a kaf and to a beth, as a comparison with the successive kaf and beth of תתכבד in line 20 shows) and the base (which has the rounded shape of a kaf) are now preserved, separately from one another. PAM 43.511 (taken on June 1960, used for the plate in DJD and representing more closely the actual state of the fragment) conclusively demonstrates the extensive deterioration. It shows the top and base further apart and renders all identification uncertain. The differences in the successive

12 DJD 34, 92.

13 Kister, “A Qumranic Parallel," 366. In a footnote Kister thanks Qimron "for confirming my reading, and for checking it with me in the original in the Israel Museum," which apparently indicates that the checking was done after the removal of the original from the Rockefeller Museum.

14 All the dates of the photographs are taken from "The Photographer's Logbook of the Photographic Session Taken at the PAM between 20.12.1947 and March 1961" reproduced in the Companion Volume to the Dead Sea Scrolls Microfiche Edition (Leiden: E.J. Brill, 1993). 
photographs raise very strongly the question of what can now be seen in the manuscript. Kister characterizes the matter carefully: "the first letter looks more like bet than kaf." The observation in this case depends strongly on a recent personal examination, and its impact vanishes when compared with the oldest photograph, 40.613 of May 1953, where the letter in question is still complete.

For 4Q417 Kister is more assertive: "the traces of bet are clear in 4Q417." But here, too, the photographs tell a different story. In the oldest photographs (PAM 41.504, taken in February 1955, the one reproduced in the Plates; and PAM 42.581, taken in June 1958), as in the later ones (PAM 43.222 and 43.516, from January and June 1960), it is evident that only part of the top of the letter has been preserved, rather curved in this case. Without the descender and the crossbar, it is simply impossible to distinguish this top as belonging to a kaf or a תתכבד beth, as again a comparison with the successive kaf and beth in line 25 of this fragment clearly shows. Here it is not the deterioration, but the kind of evidence preserved that makes certainty impossible from the beginning. Strugnell's cautious decision to mark all letters as more or less certain ${ }^{15}$ is justified.

My conclusion is that any examination of the manuscripts in their current state of deterioration cannot convincingly justify a change to the editor's reading, which is clearly supported by the oldest photographs. Kister's explanation of the line in question is certainly reasonable and gives a good argument for understanding this line as part of the previous ones and in the general context of 4QInstruction. As such, it has much to be commended. His conclusion: "If the reading ' כלי 'vessel' is abandoned, the ostensibly striking parallel proves to be entirely irrelevant, for there is no similarity whatsoever between Paul's expression and our passage either in theme or in terminology," 16 is perfectly right as far as it goes. But, since the reading "כלי "vessel" remains paleographically the most likely, Strugnell's reading of the word, and his explanation of it as a precedent for the New Testament usage, not only remains possible, but also seems best to explain the originally preserved evidence. The only way to agree with Kister's interpretation would be to assume an error of the copyist, at least in the case of $4 \mathrm{Q} 416$.

\footnotetext{
${ }^{15}$ DJD 34, 193.

${ }^{16}$ Kister, "A Qumranic Parallel," 370.
} 
2. שמים 4Q in 4Q416 1:12 and 4Q418 69 ii 12-13:

Men, angels, angelomorphic men?

My second marginal note does not involve a problem of reading, but it concerns the meaning of a common and apparently rather innocuous expression which appears three times in the preserved fragments of 4QInstruction (4Q416 1:12; 4Q 418 2c, and 4Q418 69, 12-13). The first occurrence (4Q416 1:12) is part of the Introduction to the composition, ${ }^{17}$ and reads בני השמים. The second one (4Q418 2c) is considered by the editors to overlap with the first one, since they, after a long "Codicological Excursus," 18 reject Elgvin's suggestion of considering these fragments (with some others) as belonging to a different manuscript of 4QInstruction (Elgvin's 4Q418b). Tigchelaar has convincingly proved ${ }^{19}$ that only $4 \mathrm{Q} 418$ frag. 1,2 and $2 \mathrm{~b}$ belong to a different manuscript (Tigchelaar's 4Q418*) and the isolated 4Q418 2c (so called in the transcription, DJD 34, 225, but numbered 2a on Plate XII, corresponding to the original fragment 4Q418 213), forms part of 4Q418 and overlaps with 4Q416 1 . This text, as Tigchelaar has noticed, offers the usual form of the expression in all other places at Qumran, as incorrectly transcribed by the editors. The third occurrence (4Q418 69) also preserved this most usual form בני שמים.

Since the occurrence at $4 \mathrm{Q} 4182 \mathrm{c}$ is correctly considered to overlap with the occurrence at 4Q416 1, we do not need to be further distracted by it, and we can concentrate on the two other cases where the expression appears in two different contexts (though both related to eschatological topics: judgment and eternal life) which may help us to ascertain its meaning. Both texts have been the subject of extensive

17 A position adopted by the editors (DJD 34, 19) following the reconstruction by A. Steudel and B. Lucassen, against the reconstruction proposed by T. Elgvin, "The Reconstruction of Sapiential Work A," RevQ 16/64 (1995) 559-80, and An Analysis of 4QInstruction (Hebrew University of Jerusalem Thesis: Jerusalem, 1997) 11-35, which locates 4Q416 1 later in the composition, after frag. 2. For a thorough discussion of both ways to understand the beginning of the composition, see E.J.C. Tigchelaar, To Increase Learning for the Understanding Ones. Reading and Reconstructing the Fragmentary Early Jewish Sapiential Text 4QInstruction (STDJ 44; Leiden: E.J. Brill, 2001) 175-193, and in more detail "Towards a Reconstruction of the Beginning of 4QInstruction (4Q416 Fragment 1 and Parallels)," in C. Hempel, A. Lange, H. Lichtenberger (eds.), The Wisdom Texts from Qumran and the Development of Sapiential Thought (BETL 159; Peeters, Leuven 2002, 99-126.

18 DJD 34, 226-227.

19 Tigchelaar, To Increase Learning, 61-69. 
and detailed study. ${ }^{20}$ Our question, which is closely connected to the general eschatological outlook of the composition and particularly with its notions on judgment, death, and afterlife, is: are the beings referred to in the text men, angels, or angelomorphic men?

The question seems at first sight completely artificial. On all other occasions where the expression appears in $\mathrm{Hebrew}^{21}$ or Aramaic ${ }^{22}$ texts

${ }^{20}$ Already before publication in DJD, both fragments were studied in detail in the still unpublished dissertation of T. Elgvin, An Analysis of 4QInstruction, Jerusalem 1997, 97-111; in his contribution "Early Essene Eschatology: Judgement and Salvation according to Sapiential Work A," Current Research and Technological Developments on the Dead Sea Scrolls (eds D.W. Parry and S.D. Ricks; STDJ 29; Leiden, E.J. Brill, 1996) 126-65; and in his lecture at the Scandinavian conference on the Scrolls in 1995, "The Mystery to Come: Early Essene Theology of Revelation," Qumran between the Old and the New Testaments (eds F.H. Cryer and T.L. Thompson; JSOTSup 290; Sheffield: Sheffield Academic Press, 1998) 113-50. They are also the subject of a major chapter of the dissertation of M.J. Goff, The Wordly and Heavenly Wisdom of 4QInstruction (STDJ 50; Leiden: E.J. Brill, 2003) 168-215. For 4Q416 1, see E.J.C. Tigchelaar, To Increase Learning, 175-92. For 4Q418 69, see Tigchelaar, To Increase Learning, 91-93 and E. Puech, "Apports des textes apocalyptiques et sapientiels de Qumrân à l'eschatologie du Judaïsme ancien," Wisdom and Apocalypticism in the Dead Sea Scrolls and in the Biblical Tradition (ed F. García Martinez; BETL 193; Leuven: Peeters, 2003) 133-70, and "La croyance à la resurrection des justes dans un texte qumranien de sagesse: 4Q418 69 ii," Sefer Moshe. The Moshe Weinfeld Jubilee Volume. Studies in the Bible and the Ancient Near East, Qumran and Post-Biblical Judaism (eds C. Cohen, A. Hurzitz, and S.M. Paul; Winona Lake, Indiana: Eisenbraums, 2004) 427-44. Both texts have been studied together by J.J. Collins in "The Mysteries of God. Creation and Eschatology in 4QInstruction and the Wisdom of Solomon," Wisdom and Apocalypticism in the Dead Sea Scrolls, 288-305, and in "The Eschatologicizing of Wisdom in the Dead Sea Scrolls," Sapiential Perspectives: Wisdom Literature in Light of the Dead Sea Scrolls (eds J.J. Collins, G.E. Sterling, R.A. Clements; STDJ 51; Leiden: E.J. Brill, 2004) 49-65. The most recent treatment of both texts is a contribution by Puech to a Qumran meeting held in Paris at the Collège de France in November 2004, and an article forthcoming in the $\operatorname{Rev} Q$ : "Les fragments eschatologiques de 4QInstruction (4Q416 1 et 4Q418 69 ii 81-81a, 127)" RevQ 85 (2005) 89-119. I thank Puech for allowing me to quote from this forthcoming publication.

${ }_{21}$ 1QS IV 22: "in order to instruct the upright ones with knowledge of the Most High, and to make understand the wisdom of the sons of heaven to those of perfect behavior, for those God has chosen for an everlasting covenant." DSSSE I, 79. 1QS XI:7-8: "To those who God has selected he has given them as everlasting possession; and he has given them an inheritance in the lot of the holy ones. He unites their assembly to the sons of heaven in order (to form) the council of the Community and a foundation of the building of holiness to be an everlasting plantation throughout all future ages." DSSSE I, 97. (Wise-Abegg-Cook, DSS: A New Translation, 131 and 142; translated directly as "angels" in these two cases). 1QH ${ }^{\mathrm{a}} \mathrm{XI}: 21-22$ : "The depraved spirit you have purified from great offence so that he can take a place with the host of the holy ones, and can enter in communion with the congregation of the sons of heaven." DSSSE I, 165. 1QH ${ }^{\mathrm{a}}$ XXIII: 10 (Sukenik frag. 2 I 10): "the sons of gods, to be in communion with the sons of heaven," DSSSE I, 199. 4Q181 1 ii 2: "According to the powerful deeds of God and in line with their evil, according to $\{$ the foundation 
found at Qumran, it apparently refers to heavenly beings, to angels of some sort. In the Aramaic texts (Genesis Apocryphon and Aramaic Enoch) the expression is employed consistently to name the fallen angels, presenting them in association with the Watchers, which gives the expression a rather negative connotation. In the Hebrew texts the expression is encountered only within sectarian texts $(1 \mathrm{QS}, 1 \mathrm{QH}, 4 \mathrm{QH}$ and in 4 Q181 which appears closely related to $1 \mathrm{QS}$ ) and always in the context of retribution, as is the case in 4 QInstruction. In $1 \mathrm{QS}$ IV the upright and those of perfect behaviour, that is the earthly members of the yahad, are instructed in the divine and angelic knowledge (עדעת) עליון וחכמת בני שמים , because they have been "chosen for an everlasting covenant." In 1QS XI two groups (assemblies) are clearly distinguished, the human formed by the elected and the heavenly formed by the עצי שמים יחד both destined to form a unique and eternal. The same idea is reflected in the texts of the Hodayot: communion with the angels after purification. If 4 QInstruction could be considered a Qumranic writing, there would be no doubt as to the meaning of the expression. But since this is not certain, scholars are divided on the issue.

On 4Q416 1 the phrase is part of a clear context of judgment, covering lines $10-13$. The editors' translation reads:

10 From Heaven He shall pronounce judgement upon the work of wickedness. But all His faithful Children will be accepted with favour by [Him ]

11 the end. And they shall feel dread. And all who defiled themselves in it (sc. wickedness) shall cry out in distress. For the heavens shall fear [ ]

12 The [se]as and the depths fear, And every spirit of flesh will be destroyed (?). But the sons of Heave[n] sh[all rejoice in the day]

13 [when it (sc. Wickedness) is ju]dged.

The editors note the possibility that בני אמתו in line 10 may refer to "a human group or an angelic one-theoretically, either interpretation would be possible" ${ }^{23}$ but on the basis of the use of this phrase in some Qumranic texts $\left(1 \mathrm{QH}^{\mathrm{a}} \mathrm{VI}: 29\right.$, IX:35 and X:27) to refer clearly to humans, they conclude that here it should also be interpreted in this way. The editors do not comment specifically on the meaning of in 4Q416, but from their comment: "This description of an

of their impurity \} their impurity, he delivered the sons of the he[avens] and the earth to a wicked community council." DSSSE I, 373. Other appearances of the phrase (1QH ${ }^{\mathrm{a}}$ XXVI:11, 4Q427 7 ii 18, or 4Q428 19:7) do not provide enough context to precisely discern the meaning.

22 1QapGen II:5. 16; V:3-4; VI:11 and 2Q202 1 ii 3.

23 DJD 34, 85. 
angelic judgement on wickedness is almost complete, and one can at least follow the sequence of its features in line 10-12," ${ }^{24}$ we may conclude that they consider the "sons of heaven" as angels.

Torleif Elgvin interprets both expressions as referring to angels. He considers line 10 of 4Q416 1 (line 11 on his numbering) to refer "more probably to a heavenly judgement on cosmic evil forces and fallen angels." בני משמים he says: "In line 13 we encounter שמי] 'the sons of heaven'. In 1 Enoch 6:2; 14:3 and 1QapGen II 5,16 'the sons of heavens' are the fallen angels (cf. Gen 6:2 בני האלהים, 1 Enoch $71: 1$ 'sons of the holy angels'). In this text as well as 4Q418 69 ii 12-13 'the sons of heavens' are the angels, as in 1QS IV 22; XI 8; $1 \mathrm{QH}^{\mathrm{a}}$ III 22; frag. 2 10."26

Eibert Tigchelaar considers it possible that בני אמתו may be referring to angels. His alternative translation of line 10 reads: "Or 'and all His faithful children (angels) will run to[', ${ }^{, 27}$ and in his discussion he says: "The supposition is that the בני אמתו are 'a human group'. However, if they are understood as an angelic group, we should consider the reading ירצו, 'they will run', expressing that the angels will hasten to execute some judgment or another." בני השמים As for, Tigchelaar does not comment explicitly on the expression, but his remark when dealing with the angelology of 4Q418 55 and 69 implies that he considers it to refer to angels, ${ }^{29}$ and he gives an explicit identification when dealing with the expression as it appears in 4Q418 69: "Not all details of the text are clear, but these lines contrast the elect to the "[sons?] of heaven', i.e. the angels." ${ }^{30}$

A different interpretation is given by Jörg Frey, ${ }^{31}$ who in his discussion of the רוח בשר sees in our text a reference to three distinct

\footnotetext{
${ }^{24}$ DJD 34, 83 and 85.

25 Elgvin, An Analysis of 4QInstruction, 101.

${ }^{26}$ Elgvin, "Early Essene Eschatology," 152; An Analysis of 4QInstruction, 106.

27 Tigchelaar, To Increase Learning, 176.

28 Tigchelaar, To Increase Learning, 180.

29 Tigchelaar, To Increase Learning, 220: "Some other fragments also refer to sons of heaven or the holy ones (4Q416 1; 4Q418 81 1; 4Q417 1 I 17) but 4Q418 55 and 69 ii are the only sections which deal extensively with angels." On his discussion of the expression, on p. 197, no explicit identification of the group is offered.

30 Tigchelaar, To Increase Learning, 215.

31 Jörg Frey, "The notion of 'Flesh' in 4QInstruction and the Background of Pauline Usage," Sapiential and Poetical Texts from Qumran. Proceedings of the Third Meeting of the International Organization for Qumran Studies, Published in Memory of M. Baillet (eds. D. Falk, F. García Martínez, and E. Schuller; STDJ 35; Leiden: E.J. Brill, 2000), 197-226.
} 
groups (one of whom, the בני השמים, are angels), opposed in two different camps. His interpretation of the passage merits quotation in full:

In spite of the textual lacunae, the antithetic structure is obvious. Two groups of beings face an opposite eschatological fate. The first group is characterized by wickedness, iniquity and injustice, and its members will face judgement; they will tremble with fear, and suffer final destruction. The other group is characterized by truth, and its members will be favoured by God. The members of the first group wallow in something (most probably iniquity), and are named the collective designation of כול רות בשר. The other group seems to comprise the sons of heaven and the sons of truth, i.e the angels together with the just human beings. The statement is quite clear: when God will enact his eschatological judgement and put and end to all kinds of injustice, every spirit of flesh will be destroyed. The group of (human) beings who may be called "spirit of flesh" is clearly opposed to the "sons of truth" and the "sons of heaven". This group is characterized by wickedness and injustice, and will face eschatological destruction." ${ }^{\prime 32}$

This negative understanding of רוח בשר has not gone unchallenged, of course, ${ }^{33}$ but what should interest us here is the bringing together of the angels, "sons of heaven," and the humans, בני אמתו, "the sons of truth," into one group.

Emile Puech's understanding of the expression seems to have בני השמים exolved with time, from the opinion that the expression refers to angels ${ }^{34}$ to the explicit assertion that it refers to humans. In his forthcoming contribution "Les fragments eschatologiques de $4 \mathrm{QInstruction,"} \mathrm{commenting} \mathrm{the} \mathrm{expression} \mathrm{as} \mathrm{it} \mathrm{appears} \mathrm{on} \mathrm{4Q416}$ $1: 10$, and after having recognized that in the Qumran texts it "désigne assez régulièrement les anges," he asserts: "Toutefois dans le contexte de l'Instruction, les 'fils des cieux', opposés à בשר כול רוח 'les impies', doivent designer les justes, 'les fidèles' בני אמח qui sont destinés à partager l'héritage des saints, tous ceux qui auront suivi les instructions du sage en apprenant à distinguer le bien du mal." ${ }^{35}$ And in his comment on 4Q418 69 ii he even refers to this meaning of שמים

32 Jörg Frey, "The notion of 'Flesh'," 216-17.

רוח : בשר is not a qualitative anthropological concept, but a general reference term to living beings."

${ }^{34}$ E. Puech, "Apports des textes apocalyptiques," 143: "Sa place sera dans la lumière et la gloire, en compagnie des anges, fils des cieux, dans le conseil divin et la présence de Dieux." And more explicitly when commenting on the expression as it

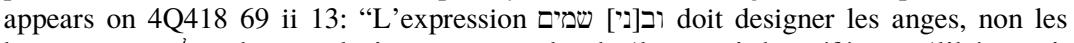
hommes, et נחלתם devrait plutôt se comprendre du 'lot, part' de préférence 'l'héritage', puisque les anges le possèdent depuis l'origine à l'exception des anges déchus qui l'ont perdu," cf. "La croyance à la résurrection des justes," 434.

${ }^{35}$ E. Puech, "Les fragments eschatologiques de 4QInstruction," 96. 
as having been already established, in order to justify his division of the text in line $14 .{ }^{36}$

Crispin Fletcher-Louis, commenting on 4Q418 69 and arguing that the expression "inheritance" and "walking in eternal light" does not apply to angels, sees in the expression בני שמים a reference to a category of being that he calls "heavenly sonship," which will include both humans and angels - the transformed righteous and the angels proper. He dismisses the editors' argument about the shift from the second to the third person plural in lines 13-15, and identifies the "elect of truth" with the "sons of heaven." He concludes: "This understanding of the "sons of heavens" as a broad category including both the transformed righteous and angels proper is in accord with the use of the expression elsewhere (e.g. 1 Enoch 101:1; 1QH ${ }^{\mathrm{a}}$ 11:22; 2 Macc 7:34)." ${ }^{\prime 37}$

All three possible of interpretations of this expression have been proposed by reputable scholars; the "sons of heavens" have been understood either as angels, or as men, or as beings belonging to a poorly defined category which assimilates the transformed righteous and the angels. In order to assess which interpretation is most convincing, it is also necessary to look at the second occurrence of the expression in 4Q418 $69 \mathrm{ii}$, where it appears after the final judgment and destruction of the "בני עולה, the "children of iniquity." What remains from lines 10-14 has been translated by the editors as follows: ${ }^{38}$

10 Vacat But you who are the truly chosen ones, Who pursue [righteousness,] Who see[ek eagerly for understanding, And who] keep vigil

11 over all knowledge, How can you say, 'We are tired of understanding, and/though we have been vigilant in pursuing knowledge'? For [the Understanding One tires not $]$ at all $t i[$ mes $]$

12 Nor does $\mathrm{He}$ become weary in all the years of eternity. Does $\mathrm{He}$ not take delight in Truth forever, And does not Knowledge [forever] serve Him? But as for the $\mathrm{S}$ [ons of]

13 Heaven, whose lot is eternal life, Will they truly say, 'We are weary of doing the works of Truth, And [we] have grown weary of them

14 At all times? Will [they] not walk in light everlasting[ ] vacat $^{39}$ [

${ }^{36}$ E. Puech, "Les fragments eschatologiques de 4QInstruction," (change to 104) 104: ““Avec eux/Vous-mêmes[. . .?' La solution dépend du sens donné à l'expression בני שמים (1. 13). On a vu ci-dessus qu'au début de l'Instruction, en 4Q416 1 12, l'expression s'opposant aux בשר כול רוח ne pouvait designer que des humains, les justes. Comme il doit logiquement en être de même ici, seul reste alors possible le sens "vousmêmes' qui reprend naturellement en inclusion le ואתם בחירי אמת de la ligne 10."

${ }^{37}$ C.H.T. Fletcher-Louis, All the Glory of Adam. Liturgical Anthropology in the Dead Sea Scrolls (STDJ 42; Leiden: E.J. Brill, 2002) 120.

${ }^{38}$ DJD 34, 283.

39 The vacat is not indicated in the transcription or translation, but it is noted in the 
If we set aside the central part, which uses the third person singular and, according to the editors, may refer to God, the thrust of the passage is the parallel drawn, with very similar wording, between the group addressed in the second person plural ("you") (the בחירי אמת), and the group of the בני שמים who are referred to in the third person plural ("they"). ${ }^{40}$ The point may be, as Tighcelaar says, "that whereas the elect get tired of toiling for understanding, the angels do not tire in eternity." human beings, as Puech does, are forced to see the point of the passage differently. In fact, Puech understands the whole passage as speaking of the same protagonists, the resurrected just ones. He even sees the third person masculine singular of line 12 as referring not to God, but in a impersonal manner to the resurrected elect ones: "Le sujet des deux verbes au singulier doit être un indéfini 'on' compris entre les deux pluriels de ce paragraphe, sans avoir à faire appel à une référence à Dieu, ainsi que le suggère plusieurs fois l'édition (pp. 289 et 283), d'autant qu'en hébreu biblique שעשע ne se rencontre jamais avec Dieu comme sujet." ${ }^{42}$

Those who see in בני שמים a reference to the category of transformed ('angelomorphic') righteous and angels, like Fletcher-Louis, also read the whole passage as referring to this category. They even try to see it from the perspective of cultic anthropology, a perspective that, according to Fletcher-Louis, "makes ... the best sense of the rhetoric of 4Q418 69, particularly the movement from a second person address in lines 10-11 to a third person in line 13-14 where the addressees are directed to the ontology of worship." ${ }^{\prime 3}$

The identification of the editors, in this case, is formal: the שמי are angels, and no other possible identification applies:

\footnotetext{
"Notes on the readings," DJD 34, 283. It is evident on PAM 41.907, but even 43.480, the plate printed, is clear. This facilitates the division of the unit.

${ }^{40}$ DJD 34, 290: "It would seem that the two questions are related by a contrast between their speakers, שמים בני and the בחירי אמת , and also between their contents."

${ }^{41}$ Tigchelaar, To Increase Learning, 215.

${ }^{42}$ Puech, "La croyance à la résurrection des justes," 434. In "Les fragments eschatologiques" he does not give new arguments, but clearly asks the question: "A qui ren-

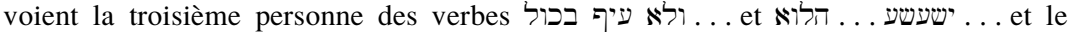
suffix du verbe suivant תשרתנו ? A Dieu ou à un être humain ?" In his answer, Puech moves from the impersonal he postulates to the plural of the previous lines: "Dans ces ennoncés de vérités proverbiales, on le comprend mieux d'un humain, des élus à la recherché de la vérité-fidélité, eux qui se fatiguent et qui, seuls, puevent se décourager ..."

${ }^{43}$ Fletcher-Louis, All the Glory of Adam, 120.
} 
To understand 'sons of heaven whose lot is eternal life' as the angels seems inescapable; that it should be another description of a human and sectarian group, the elect, etc., though theoretically possible, is ruled out by the fact that the text has moved from being an address in the 2nd plural to being a question in the $3 \mathrm{rd}$ plural; and nothing points to the presence here of a distinct (3rd person) human group nor the likelihood that the בחירי מתא (line 10) were an angelified group of humans. ${ }^{44}$

What is most surprising about the different positions taken on the matter is the lack of real argumentation put forth to sustain the readings. The options chosen, except in the case of the editors, seem to be directed by presuppositions about what the text should be saying when compared to other Qumran texts. This is most clear in the case of FletcherLouis, who forces the text into his "angelomorphic liturgical anthropology," but it is equally clear in Puech's intention to prove that this text is also speaking of the resurrection of the righteous and that the resurrected righteous can therefore be called "sons of heavens." Both scholars apparently overlook that if 4QInstruction is read in a "Qumran context," all meanings of the expression "sons of heavens" other than "angels" would directly contradict the meaning it has when used within the sectarian writings. Making the "angels" humans completely blurs the differences between the two groups, of which it is asserted that they are (or will be) forming a single community (see the relevant texts in note 20). Only by keeping the two entities distinct do the Qumran texts make sense.

The two passages where the expression appears in $4 \mathrm{Q}$ Instruction are clearly addressing the issue of final judgment (that much is made explicit by 4Q416 110 and 4Q418 69 ii 7, independently of the human or angelic interpretation one would give to the expressions used in this case) and the fate of the righteous after the judgment. Participation in the heavenly world seems to form part of this fate, and therefore fellowship with the angels seems to be their destiny.

Collins expresses the thrust of our passage this way:

In fact, the passage clearly supposes that the human righteous share the lot of the angels, and may hope for eternal life in the council of the divine ones. The idea that the righteous human could be elevated to share the life of the angelic host is well attested in the last centuries before the common era. In the early apocalypses of Daniel and Enoch, this is the fate of the righteous after death. In the Hodayot from Qumran, the angelic state can be anticipated even in this life. ${ }^{45}$

\footnotetext{
${ }^{44}$ DJD 34, 290.

45 J.J. Collins, "The Mysteries of God," 296.
} 
And Matthew Goff thus concludes his analysis of the eschatology of 4QInstruction:

The relationship of the righteous to the angelic world asserted in the Hodayot represents a bolder claim than that of 4 QInstruction. The Hodayot can be said to have a 'realized eschatology', since the elect are depicted as enjoying fellowship with the angels in the present. In 4QInstruction, by contrast, full participation with the angelic world is realized after death. ${ }^{46}$

As it is the case in the sectarian texts, here, too, blurring the distinction between angelic and human beings will only obscure the reward of the righteous and their participation in the heavenly world. The on 4QInstruction are angels. The editors' understanding of the expression is the most convincing position offered in light of the composition. After examining the alternatives proposed, their understanding of the text on its own, without forcing it into a qumranic frame, but also without forgetting the parallels other qumranic manuscripts provide, not only remains possible, but also offers us the best explanation of the expression used.

These two small notes, offered to John Strugnell as a token of appreciation of his work and with the most sincere gratitude for the wonderful memories of our time together in Jerusalem during the seventies, both prove a single point: his (and D. Harrington's) work on $4 \mathrm{QInstruction}$ has proved to be of sustained value. It has opened new avenues of research on these manuscripts and stimulated the work of other scholars in their search for meaning; but the basic insights of the editio princeps remain the best guide to understanding this document, a document which is fundamental to tracing the development of the Jewish wisdom tradition.

${ }^{46}$ M.J. Goff, The Worldly and Heavenly Wisdom, 212. 